\section{Studia z Filologii Polskiej i Słowiańskiej}

DOI: $10.11649 /$ sfps. 2165
Studia z Filologii Polskiej i Słowiańskiej, 55

Warszawa 2020

Article No. 2165

\section{Citation:}

Kozłowska-Doda, J. (2020). Wybór publikacji Hienadzia Cychuna wyrazem wszechstronności zainteresowań slawistycznych autora. Studia z Filologii Polskiej i Słowiańskiej, 55, Article 2165. https://doi.org/10.11649/sfps.2165

\author{
Jadwiga Kozłowska-Doda \\ (Uniwersytet Marii Curie-Skłodowskiej w Lublinie)
}

\title{
Wybór publikacji Hienadzia Cychuna wyrazem wszechstronności zainteresowań slawistycznych autora
}

\begin{abstract}
Rec.: Генадзь Цыхун, Прастора мовы. Моўныя сувязі. Гісторыя слоў: выбраныя працы, уклад. Яўгенія Волкава, Беларуская навука. Мінск, 315 ss.
\end{abstract}

Nazwisko białoruskiego slawisty Hienadzia Cychuna jest w Polsce dobrze znane. Uczony nieraz publikował w polskich czasopismach i recenzowanych tomach swoje artykuły ${ }^{1}$, uczestniczył w licznych konferencjach naukowych i projektach badawczych, wreszcie 10 lat poświęcił pracy dydaktycznej w Katedrze Filologii Białoruskiej na Uniwersytecie w Białymstoku (Siegień, 2013).

${ }^{1}$ Bibliograficzna baza danych światowego językoznawstwa slawistycznego iSybisław tylko od roku 1999 notuje 39 pozycji, wśród nich artykuły w cenionych w środowisku czasopismach polskich „Acta Universitatis Lodziensis. Folia Linguistica”, „Acta Albaruthenica”, „Etnolingwistyka: problemy języka i kultury”, „Studia Russica”, „Slavia Orientalis”, „Studia z Filologii Polskiej i Słowiańskiej” oraz białoruskich „Беларуская лінгвістыка”, „Тэрміналагічны бюлетэнь”, monografie, rozdziały w monografiach i redakcje książek. Wykaz jest niestety niekompletny.

This is an Open Access article distributed under the terms of the Creative Commons Attribution 3.0 PL License (creativecommons.org/licenses/by/3.0/pl/), which permits redistribution, commercial and non-commercial, provided that the article is properly cited. (c) The Author(s) 2020.

Publisher: Institute of Slavic Studies, Polish Academy of Sciences

[Wydawca: Instytut Slawistyki Polskiej Akademii Nauk] 
Sylwetka profesora H. Cychuna od 1963 roku wiąże się nierozerwalnie z Instytutem Językoznawstwa imienia Jakuba Kołasa Narodowej Akademii Nauk Białorusi. Profesor Cychun jest bałkanistą (bułgarystą i macedonistą), specjalistą od zagadnień związanych z kształtowaniem i funkcjonowaniem bałkańskiej ligi językowej ${ }^{2}$, a także od szeroko rozumianych kontaktów językowych, etymologii i historii slawistyki. Jest też doktorem honoris causa Uniwersytetu Sofijskiego imienia św. Klemensa z Ochrydy i członkiem zagranicznym Macedońskiej Akademii Nauk i Sztuk. Brał udział w dziesięciu Międzynarodowych Kongresach Slawistów (MKS), na których wygłosił dziewięć referatów autorskich oraz jeden współautorski. Jest członkiem pięciu komisji MKS. Od 1966 r. wykładał w Białoruskim Uniwersytecie Państwowym język bułgarski i macedoński oraz szereg przedmiotów specjalistycznych. Pod jego kierunkiem przygotowano i obroniono siedem prac doktorskich. O tych i innych faktach z życia zawodowego H. Cychuna czytelnik dowie się ze szkicu biograficznego, umieszczonego na początku książki (Антропаў \& Запрудскі, 2018).

Wyboru prac dokonała i przygotowała je do druku Jauhienija Wołkawa, wieloletni pracownik naukowy Zakładu Slawistyki i Teorii Języka IJ NANB (wcześniej - Zakład Językoznawstwa Słowiańskiego i Teoretycznego), którym profesor Cychun kierował od 1991 do 2005 roku. W krótkim wstępie J. Wołkawa podkreśla, że chociaż wszystkie 52 teksty ukazały się wcześniej drukiem, do niniejszego wydania zostały one przez autora poprawione i gruntownie rozszerzone. Żadne z umieszczonych tu opracowań nie było drukowane w wydanym w 2012 r. wyborze prac H. Cychuna (Цыхун, 2012), który, co warto zaznaczyć, został pozytywnie zaopiniowany w Polsce (Smułkowa, 2014).

Ciekawa i jednocześnie budząca ogromny podziw dla naukowych zainteresowań i wszechstronności uczonego wydaje się przynależność tematyczna poszczególnych prac: Badania arealne (brus. Арэалагічныя даследаванні), Zagadnienia historycznojezykowe (brus. Гістарычна-моўныя праблемы), Kontakty językowe i międzyjęzykowe paralele (brus. Міжмоўныя кантакты і паралелі), Socjolingwistyka i ekolingwistyka (brus. Сацыялінгвістыка і экалінгвістыка), Studia etnolingwistyczne (brus. Этналінгвістьчныя эцюдь), Etymologia i onomastyka (brus. Этыммалогія і анамастыка), Varia.

${ }^{2}$ Jedną z ważniejszych publikacji uczonego w tym zakresie stanowi jego książka habilitacyjna (Цыхун, 1981). 
Dział pod tytułem Badania arealne ${ }^{3}$ zawiera osiem bardziej lub mniej obszernych tekstów. Dwa z nich są referatami wygłoszonymi podczas MKS (Цыхун, 1983, 2013). Uwagę warto skupić na pojęciu lingwistyki arealnej, która w nauce polskiej nie jest popularną metodą studiów językoznawczych, rzadko jest też omawiana na zajęciach dydaktycznych z zakresu metodologii badań lingwistycznych. Metoda arealna, jak zaznacza Roman Jakobson, powołując się na badania amerykańskiego językoznawcy Josepha Harolda Greenberga, jest komplementarna względem metody genetycznej i typologicznej w ocenie faktów językowych (Якобсон, 1963, s. 97).

Metoda ta koncentruje się na czynniku terytorialnym, a określenie areat jest rozumiane jako zasięg rozpowszechnienia konkretnych cech języków lub grup językowych. Głównym celem badań arealnych jest analiza kształtowania się tzw. areałów językowych, zwanych też ligami językowymi, czyli grup języków niespokrewnionych ze sobą genetycznie, które wytworzyły wiele cech wspólnych w procesie długotrwałych wzajemnych kontaktów na wspólnym terenie. Lingwistyka arealna bada genezę poszczególnych osobliwości językowych na konkretnym terenie, kierunek ekspansji innowacji, ustala tereny zachowania archaizmów, centrum, peryferie oraz strefę dyfuzji. Na podstawie tych danych ocenia charakter strefy dialektalnej (centralna, przejściowa lub marginalna) oraz areału dystrybucji faktów językowych (innowacyjny, dyfuzyjny/przejściowy lub archaiczny) (por. Нерознак, 1990, s. 685). Jak podkreśla Kwiryna Handke, teoria arealna „wypączkowała” z dialektologii jako koncepcja interpretacyjna. Ma szerokie zastosowanie w wielu kierunkach językoznawstwa (np. etnogeneza, pochodzenie i pokrewieństwo języków i inne) (Handke, 1986, s. 43).

W recenzowanym opracowaniu Cychun stwierdza, że „lingwistyka arealna interpretuje fakty językowe, uzyskane przez dialektologię i lingwogeografię", konkludując, że jej zadaniem jest rozstrzyganie zagadnień teoretycznych (Цыхун, 2018, s. 19). Słowiańska lingwistyka arealna może pomóc ujawnić osobliwości językowe całej społeczności słowiańskiej w kontekście innych grup językowych - uważa Cychun. Uczony zastanawia się nad przydatnością w slawistyce koncepcji „lingwistyki przestrzennej” (linguistica spaziale) Matteo Giulio Bartoliego, która opiera się na zasadzie „metropolia (centrum) - prowincja”, i stwierdza, że brak jest na terenie prasłowiańszczyzny tak znaczącego centrum, jakim był Rzym i jego okolice w świecie romańskim. W ślad za Tadeuszem

3 Tytuł ten można też przetłumaczyć jako Badania terytorialne, ale wtedy niewidoczny będzie związek z tradycją badań arealnych. 
Milewskim wnioskuje, że świat Słowian nie miał stabilnego centrum. Przed rozpadem wspólnoty prasłowiańskiej „Słowianie mieszkali na północ od Karpat i tam leżało centrum ich innowacji językowych" (Milewski, 1966, s. 137). Po rozpadzie powstały osobne struktury mające własne centra i peryferia, lecz na ślady pierwotnego areału wskazują konkretne właściwości językowe. W tym kontekście Cychun zwraca uwagę na pewne sprzeczności metodologiczne we współczesnej slawistyce, mianowicie utożsamianie centrum wspólnoty terytorialnej z centrum powstania i rozpowszechnienia się innowacji językowych oraz traktowanie peryferii wyłącznie jako strefy konserwacji archaicznych zjawisk lingwistycznych (Цыхун, 2018, s. 20). Peryferie mogą być zarówno strefą przechowania archaizmów, jak i miejscem kształtowania się innowacji twierdzi Cychun za Zdzisławem Stieberem (Stieber, 1974, ss. 239-241).

Już w 1998 roku Cychun zaproponował rekonstrukcję pierwotnej struktury areału Słowiańszczyzny typu „centrum - peryferia” na zasadzie: im więcej innowacji prasłowiańskich wiąże współczesny język z innymi słowiańskimi, tym bliżej centrum arealnej prasłowiańszczyzny mieścił się jego ówczesny odpowiednik (Цыхун, 1998a, s. 76). Im więcej oryginalnych dialektyzmów, nieznanych w innych językach, posiada konkretny język słowiański, tym dalej od centrum występuje, i odwrotnie. Badacz, wychodząc z założenia, że centralne miejsce języka w rodzinie językowej jest związane się z jego najmniejszą oryginalnością, stwierdza (na podstawie materiału zaczerpniętego z Ogólnosłowiańskiego atlasu językowego), że język białoruski charakteryzuje najmniejsza liczba oryginalnych dialektyzmów wśród języków wschodniosłowiańskich (Цыхун, 2018, s. 23).

Kolejnym zadaniem słowiańskiej lingwistyki arealnej, które dostrzega Hienadź Cychun, jest ustalenie centrów ukształtowania i rozpowszechniania peryferyjnych innowacji, obecnych także w środku struktury arealnej (Цыхун, 2018, s. 26). Takie miejsca, jak pokazują badania dialektologiczne, są zlokalizowane na prowincji, z daleka od centrów przemysłowych. Na przykładzie obszaru północnosłowiańskiego Cychun prześledził następujące zjawiska fonetyczne: przejście $g>h$, stwardnienie $r$ ', akanie, ciekanie i dziekanie, i stwierdził, że nawarstwianie się na siebie areałów innowacyjnych pozwala uznać lokalizację języka białoruskiego w północnosłowiańskim areale za położoną najbliżej centrum (Цыхун, 2018, s. 33).

W kontekście lingwistyki arealnej mieści się również tekst pt. O bałtycko-słowiańskiej lidze językowej. Jedni badacze lokalizują tę ligę w pasie pogranicza białorusko-litewskiego, strefie aktywnej dwu- i wielojęzyczności. Inni rozumieją 
ją szeroko, tzn. jako teren rozpowszechnienia zarówno języków słowiańskich, jak i bałtyckich, np. białoruskiego, ukraińskiego, polskiego, kaszubskiego, litewskiego oraz wspólnych cech językowych. Wychodząc z założenia, iż każdą ligę językową charakteryzuje struktura „centrum - peryferie”, można sądzić, że pogranicze bałtycko-słowiańskie zlokalizowane jest najbliżej centrum, ponieważ charakteryzuje się największą liczbą wspólnych zjawisk. Na podstawie danych lingwogeografii profesor Cychun analizuje proces tworzenia kalk (syntaktycznych, morfologicznych i, przede wszystkim, leksykalnych), na podstawie czego wnioskuje, że granica strefy centralnej bałtycko-słowiańskiej ligi sięga południa i południowego wschodu Białorusi, z kolei na styku strefy zapożyczeń i strefy kalk nagrano derywaty hybrydowe (podobieństwo formalne wyrazów różnych języków prowadzi do zmian semantycznych). Lingwista konstatuje trudności ustalenia centrum irradiacji wspólnych innowacji w granicach ligi (także bałkańskiej ligi językowej), aczkolwiek w kontekście bałtycko-słowiańskiej wspólnoty językowej podkreśla, że bardzo często takie centra automatycznie utożsamia się z terenem bałtyckim, nie zawsze jest brany pod uwagę fakt występowania podobnych struktur na oddalonych obszarach słowiańskich (zwłaszcza południowosłowiańskich) (Цыхун, 2018, s. 51).

Dział zatytułowany Zagadnienia historycznojęzykowe rozpoczyna się od artykułu - hasła encyklopedycznego - na temat języka białoruskiego przygotowanego pierwotnie dla niemieckiego Leksykonu języków Europy Wschodniej (Okuka \& Krenn, 2002). Po prawie dwóch dziesięcioleciach tekst nie stracił na aktualności. Inne zagadnienia poruszane w tym dziale dotyczą głównie terminologii naukowej.

Część pt. Kontakty językowe i międzyjęzykowe paralele prezentuje artykuły na temat podobnych zjawisk (leksykalnych, słowotwórczych) w językach, które nie sąsiadują ze sobą. Autor podejmuje także refleksję nad terminologią i semantyką poszczególnych pojęć z zakresu kontaktów językowych, jak np. strefa kontaktów (brus. кантактная зона) і рrzепіkanie (brus. пранікненне).

Na uwagę zasługuje problematyka poruszona w dziale Socjolingwistyka i ekolingwistyka. Teksty tego działu prezentują zagadnienie tzw. trasianki ${ }^{4}$, które jest roz-

${ }^{4}$ Elżbieta Smułkowa w recenzji pisze: „Mianem trasianki określa się na Białorusi idiolekty osób ze zróżnicowanym białoruskim podłożem dialektalnym, które w swoim zamierzeniu mówią po rosyjsku [...]. Jest to swoista indywidualna mieszanina językowa, w której można wprawdzie przewidzieć określony zasób słownictwa rosyjskiego, czy pewne przyswojone zwroty i cechy wymowy, trudno jednak dopatrywać się systemu językowego, [...]”. Smułkowa kontynuuje: „trasianką możemy równie dobrze nazywać okazjonalne mówienie po białorusku osób z inteligencji, 
patrywane z perspektywy istoty zjawiska (,język czy mówienie”, de Saussure’owskie langue czy parole) oraz szeroko rozumianego pojęcia ekologii językowej. Lingwista podziela pogląd, że w naturalnym rozwoju każdego języka wśród procesów zachodzących podczas kontaktów terytorialnych można wyróżnić tak procesy integracyjne z innymi językami, jak i dyferencjalne. Jednak we współczesnym globalnym świecie, jak twierdzi Autor, często dochodzi do świadomej, „sztucznej” integracji i tak jest również w dziedzinie kontaktów językowych. Cychun przedstawia podłoże teoretyczne intensywnych kontaktów językowo-kulturowych, które prowadzą do:

- asymilacji, tj. zaniku jednego z sąsiadujących języków;

- akomodacji: wzajemnego dostosowania na poziomie formalnym przy jednoczesnym zachowaniu cech genetycznych; jeśli dotyczy grupy języków jednego terytorium, prowadzić może do kształtowania się lig językowych;

- kontaminacji: zmieszania poprzez uproszczenie struktur języków kontaktujących się ze sobą, najwyższy poziom integracji (Цыхун, 2018, s. 211).

Warunkiem niezbędnym na drodze kształtowania się ligi językowej jest czynna dwujęzyczność i wielojęzyczność. Analiza osobliwości bałkańskiej ligi językowej pozwoliła Cychunowi sformułować następny wniosek: cechy wspólne mają charakter policentryczny, tzn. poszczególne innowacje rozpowszechniały się z różnych centrów, a w formowaniu ligi brały udział różne języki. Wymienione zagadnienia nie wyczerpują problematyki ekologii językowej, Autor poświęca także uwagę m.in. słowiańskim mikro- i makrojęzykom oraz samoidentyfikacji językowej w świetle ekolingwistyki.

Studia etnolingwistyczne nawiązują do badań terenowych gwar i kultury Polesia w ramach ekspedycji pod kierunkiem Nikity I. Tołstoja. Dział otwiera artykuł, poświęcony kształtom krzyży na mogiłach na Polesiu, zwanych m.in. prychoromami, narubami, prykładami. Buduje się je z drewnianych belek łączonych w narożach (węgłach) na zamki z ostatkami lub bez nich. Jak dowodzi autor tekstu, motyw domu w białoruskiej obrzędowości pogrzebowej pojawia się zarówno w nazwie trumny damawina, tj. w danych stricte językowych, jak i w danych określanych przez etnolingwistów lubelskich jako „przyjęzykowy”

które na co dzień posługują się językiem rosyjskim, o czym nie raz miałam okazję przekonać się, zwłaszcza w nielingwistycznych kontaktach naukowych" (Smułkowa, 2014, s. 214).

${ }^{5}$ Niniejszy temat był poruszany przez badacza już wcześniej (Цыхун, 1998b). Założenia metodologiczno-badawcze dyscypliny oraz dorobek polskich językoznawców w zakresie ekologii językowej opisuje m.in. Włodzimierz Wysoczański (Wysoczański, 1999). 
kontekst wypowiedzi (por. Bartmiński, 1996, s. 14), mianowicie w wyobrażeniach trumny jako 'domu zmarłego (bez drzwi i okien)' oraz w kształtach nagrobnych krzyży (i ich nazwach: prychoromy, naruby itd.).

W dziale Etymologia i onomastyka mieści się blisko dwadzieścia niedługich tekstów. Mowa w nim m.in. o niewielkim słowniku leksyki gwarowej zebranej przez uczniów z miejscowości Alpień w okolicach Turowa na Polesiu. Okazało się, że słownik zawiera wyrazy, których nie ma w 5-tomowym Słowniku turowskim (Крывіцкі, 1982-1987) (gwoli ścisłości można dodać, że H. Cychun jest jednym z pięciu autorów tego słownika), a które mogłyby się znaleźć w opracowywanym Słowniku etymologicznym języka białoruskiego (Мартынаў, 1978-1993; Цыхун, 2004-2017), redagowanym obecnie przez profesora Cychuna. Lingwista odnalazł w słowniku gwarowym także znaczenia wyrazów znanych, ale z inną semantyką, i dowiódł, że zanotowane nowe znaczenia mogą pomóc wyjaśnić pochodzenie poszczególnych derywatów znacznie szerzej używanych na terenie wschodniej Słowiańszczyzny.

Czytelnik znajdzie także etymologie poszczególnych nazw własnych, np. Grodno (brus. Гродна), Моzуrz (brus. Мазыр), Коруl (brus. Капьль), Łohojsk (brus. Лагойcк), oraz hydronimów, np. Łosośna (brus. Ласоснa), Swisłocz (brus. Свіслач), Wereciejka (brus. Верацейка), Istoczanka (brus. Істачанка). Ponadto lingwista rozważył modele słowotwórcze nazw własnych z poematu Jakuba Kołasa Nowa ziemia, etymologię spójnika $\kappa e / \kappa i(k i e / k i)$ 'i’ oraz wielu innych wyrazów (nр. подль, прыцукрасны, скем/шкем 'lis', алуха 'koniec, śmierć', суконнікі 'placki ziemniaczane'). Jeden z tekstów poświęcony jest pochodzeniu wyrazów zanotowanych w gwarach mieszanych Białostocczyzny. Trzeba podkreślić, że rozważania etymologiczne Cychuna bazują nie tylko na związkach formalnych lub podobieństwie fonetycznym. Językoznawca bierze pod uwagę szeroki kontekst, tj. kryteria terytorialne, semantyczne oraz historyczno-kulturowe.

W dwóch artykułach umieszczonych w dziale Varia zanalizowana została norma leksykalna w języku słowackim oraz zagadnienia związane $\mathrm{z}$ transliteracją tekstów Tatarów Wielkiego Księstwa Litewskiego zapisanych pismem arabskim. Trzeba podkreślić, że Profesor H. Cychun brał udział w projekcie filologiczno-historycznego opracowania oraz krytycznego wydania tzw. tefsiru Tatarów WKL z drugiej połowy XVI wieku, tj. pierwszego przekładu Koranu na język polski, grant NPRH nr $12 \mathrm{H} 12004181$ (Projekt „Tefsir”, b.d.).

Wybór publikacji opatrzono indeksem omawianych haseł, który skutecznie usprawnia dotarcie do poszczególnych zagadnień językowych omówionych $\mathrm{w}$ monografii. Brakuje, moim zdaniem, pełnego wykazu publikacji profesora 
Hienadzia Cychuna, którego, nawiasem mówiąc, nie znajdziemy też w wydanym w 2012 roku wyborze autorskich opracowań uczonego, a który nie tylko uzmysłowiłby ogrom pracy i zaangażowanie w rozwój nowych kierunków językoznawstwa tego zasłużonego dla slawistyki światowej badacza, lecz także pomógłby w odnalezieniu konkretnych zagadnień szczegółowych.

Monografia naukowa cechuje się przyzwoitą szatą graficzną i wykonaną na wysokim poziomie pracą edytorską. Wydanie zawiera także fotografie $\mathrm{z}$ archiwum prywatnego Hienadzia Cychuna, które przedstawiają rodzinną miejscowość uczonego oraz ukazują Cychuna jako ucznia, studenta, doktoranta, chórzystę, badacza terenowego, uczestnika konferencji, kierownika zakładu, zasłużonego i cenionego uczonego, a także jako syna i kolegę.

Praca polecana jest filologom slawistom oraz wszystkim, których interesuje język białoruski osadzony w szerokim kontekście słowiańskim.

W latach 1995-1998 miałam przyjemność pracować pod kierunkiem profesora H. Cychuna. Z jego ust padło wówczas wiele cennych uwag (merytorycznych, metodologicznych, technicznych i, jak zwykliśmy to określać, życiowych). Do serca wzięłam sobie jedną: by robić w życiu to, co daje satysfakcję, i żeby się nie bać podejmować nowych trudnych tematów. Tak też postępuje sam Profesor, czynnie kontynuując swoją drogę naukową. O jego otwartości na metodologię, narzędzia i zagadnienia językowe inny uczeń Profesora, dziś jego współpracownik, Siarhiej Zaprudski pisał następująco:

H. A. Cychunowi właściwa jest stała chęć rozszerzenia i pogłębienia swojego warsztatu metodologicznego oraz narzędzi naukowych. Jako prawdziwego uczonego charakteryzuje go ciągłe dążenie do rozwoju, do bycia mobilnym i gotowym do formułowania odpowiedzi na pytania aktualne dla białorutenistyki i slawistyki

[Г. А. Цыхуну характэрна заўсёднае жаданне пашыраць і паглыбляць свой метадалагічны варштат і навуковы інструментарый, уласцівае сапраўдным вучоным імкненне не стаяць на месцы, быць мабільным і адказваць на тыя пытанні, якія ставіць перад беларускай і славістычнай навукай жыццё] (Запрудскі, 2011, s. 176).

\section{Bibliografia}

Bartmiński, J. (1996). O Słowniku stereotypów i symboli ludowych. W J. Bartmiński (Red.), Słownik stereotypów i symboli ludowych: T. 1. Kosmos (ss. 9-34). Wydawnictwo Uniwersytetu Marii Curie-Skłodowskiej.

Handke, K. (1986). Dialektologia i inne nauki. Acta Universitatis Lodzensis: Folia Linguistica, 12, 37-46. 
Jadwiga Kozłowska-Doda Wybór publikacji Hienadzia Cychuna wyrazem wszechstronności ...

Milewski, T. (1966). Archaizmy peryferyczne obszaru prasłowiańskiego. W Sprawozdania $z$ posiedzeń Komisji PAN: Oddział w Krakowie (ss. 134-137). Państwowe Wydawnictwo Naukowe, Oddział w Krakowie.

Okuka, M., \& Krenn, G. (2002). Wieser Enzyklopädie des europäischen Ostens: T. 10. Lexikon der Sprachen des Europäischen Ostens. Wieser Verlag.

Projekt „Tefsir”. (b.d.). http://www.tefsir.umk.pl/o,2,zespol-projektowy.html

Siegień, B. (2013). Katedra Filologii Białoruskiej Uniwersytetu w Białymstoku - historia i stan obecny. Białorutenistyka Białostocka, 5, 503-508. https://doi.org/10.15290/bb.2013.05.34

Smułkowa, E. (2014). Цыхун, Генадзь. Выбраныя працы: Беларусістыка, славістыка, арэальная лінгвістыка. - Мінск 2012. - 370 c. [Recenzja książki]. Rocznik Slawistyczny / Revue Slavistique, 63, 210-216.

Stieber, Z. (1974). O archaizmach i innowacjach peryferycznych. W J. Kuryłowicz (Red.), Studia indoeuropejskie: T. 37. Ioanni Safarewicz septuagenario ab amici, collegis, sodalibus animo oblatum gratis imo (ss. 239-241). Zakład Narodowy im. Ossolińskich; Polska Akademia Nauk Oddział w Krakowie.

Wysoczański, W. (1999). Ekologia języka jako dyscyplina heterogenicznego opisu języka. Biuletyn Polskiego Towarzystwa Językoznawczego, 55, 63-76.

Антропаў, М., \& Запрудскі, С. (2018). Генадзь Цыхун: Нарыс жыцця і навуковай дзейнасці. W Г. Цыхун, Прастора мовы: Моўныя сувязі: Гісторыя слоў: Выбраныя працьы (Я. Волкава, Red.; ss. 8-17). Беларуская навука.

Запрудскі, С. (2011). Генадзь Апанасавіч Цыхун (да 75-годдзя з дня нараджэння). Беларуская лінгвістыка, 2011(67), 174-178.

Крывіцкі, А. А. (Red.). (1982-1987). Тураўскі слоўнік (T. 1-5). Навука і тэхніка.

Мартынаў, В. У. (Red.). (1978-1993). Этымалагічны слоўнік беларускай мовы (Т. 1-8). Навука і тэхніка.

Нерознак, В. П. (1990). Ареальная лингвистика. W В. Н. Ярцева (Red.), Лингвистический энииклопедический словарь (ss. 43-44). Советская энциклопедия.

Цыхун, Г. А. (1981). Типологчческие проблемы балканского языкового ареала. Наука и техника.

Цыхун, Г. А. (1983). Паўднёваславянска-ўсходнеславянскія моўныя сувязі (да праблемы славянскага ўкладу у балканскі моўны саюз). Навука і тэхніка.

Цыхун, Г. А. (1988). Арэальная тыпалогія славянскіх мой: Прынцыпы і напрамкі даследавання: Даклад на Х Міжнар. з’ездзе славістаў. Навука і тэхніка.

Цыхун, Г. А. (1998а). Арэальная структура праславяншчызны. W J. Rusek \& W. Boryś (Red.), Prasłowiańszczyzna i jej rozpad (ss. 73-77). Wydawnictwo „Energeia”.

Цыхун, Г. А. (1998b). Славянскія мовы у святле экалінгвістыкі: Даклад на ХІІ Міжнар. з'езде славістац̆. Беларускі камітэт славістаў.

Цыхун, Г. А. (Red.). (2004-2017). Этымалагічны слоўнік беларускай мовы (Т. 9-14). Беларуская навука.

Цыхун, Г. А. (2012). Выбраныя пращы: Беларусістыка, славістыка, арэальная лінгвістыка. Беларуская навука. 
Jadwiga Kozłowska-Doda Wybór publikacji Hienadzia Cychuna wyrazem wszechstronności ...

Цыхун, Г. А. (2013). Аспекты славянскай арэальнай лінгвістыкі: Дакл. на XV Міжнар. з'ездзе славістаў. Права і эканоміка.

Цыхун, Г. А. (2018). Прастора мовы: Моўныя сувязі: Гісторыя слоў: Выьбраныя працы (Я. Волкава, Red.). Беларуская навука.

Якобсон, Р. (1963). Типологические исследования и их вклад в сравнительно-историческое языкознание. W В. Звегинцев (Red.), Новое в лингвистике (Cz. 3, ss. 95-105). Издательство иностранной литературы.

\section{Bibliography (Transliteration)}

Antropaŭ, M., \& Zaprudski, S. (2018). Henadz' Tsykhun: Narys zhytstsia i navukovaĭ dzeĭnastsi. In H. Tsykhun, Prastora movy. Moŭnyia suviazi. Historyia sloŭ: Vybranyia pratsy (I. Volkava, Ed.; pp. 8-17). Belaruskaia navuka.

Bartmiński, J. (1996). O Słowniku stereotypów i symboli ludowych. In J. Bartmiński (Ed.), Słownik stereotypów i symboli ludowych: Vol. 1. Kosmos (pp.9-34). Wydawnictwo Uniwersytetu Marii Curie-Skłodowskiej.

Handke, K. (1986). Dialektologia i inne nauki. Acta Universitatis Lodzensis: Folia Linguistica, 12, 37-46.

IAkobson, R. (1963). Tipologicheskiie issledovaniia i ikh vklad v sravnitel'no-istoricheskoe iazykoznanie. In V.Zvegintsev (Ed.), Novoe v lingvistike (Pt. 3, pp. 95-105). Izdatel'stvo inostrannoŭ literatury.

Kryvitski, A. A. (Ed.). (1982-1987). Turaŭski sloŭnik (Vols. 1-5). Navuka i tėkhnika.

Martynaŭ, V. U. (Ed.). (1978-1993). Étymalahichny sloŭnik belaruskă movy (Vols. 1-8). Navuka i tèkhnika.

Milewski, T. (1966). Archaizmy peryferyczne obszaru prasłowiańskiego. In Sprawozdania z posiedzeń Komisji PAN: Oddział w Krakowie (pp. 134-137). Państwowe Wydawnictwo Naukowe, Oddział w Krakowie.

Neroznak, V. P. (1990). Areal'naia lingvistika. In V. N. IArtseva (Ed.), Lingvisticheskĭ entsiklopedicheskiŭ slovar' (pp. 43-44). Sovetskaia èntsiklopediia.

Okuka, M., \& Krenn, G. (2002). Wieser Enzyklopädie des europäischen Ostens: Vol. 10. Lexikon der Sprachen des Europäischen Ostens. Wieser Verlag.

Projekt “Tefsir”. (n.d.). http://www.tefsir.umk.pl/o,2,zespol-projektowy.html

Siegień, B. (2013). Katedra Filologii Białoruskiej Uniwersytetu w Białymstoku - historia i stan obecny. Białorutenistyka Białostocka, 5, 503-508. https://doi.org/10.15290/bb.2013.05.34

Smułkowa, E. (2014). Tsykhun, Henadz'. Vybranyia pratsy: Belarusistyka, slavistyka, areal'naia linhvistyka. - Minsk 2012. - 370 s. [Review of the book]. Rocznik Slawistyczny / Revue Slavistique, 63, 210-216.

Stieber, Z. (1974). O archaizmach i innowacjach peryferycznych. In J. Kuryłowicz (Ed.), Studia indoeuropejskie: Vol. 37. Ioanni Safarewicz septuagenario ab amici, collegis, sodalibus animo oblatum gratis imo (pp. 239-241). Zakład Narodowy im. Ossolińskich; Polska Akademia Nauk Oddział w Krakowie. 
Jadwiga Kozłowska-Doda Wybór publikacji Hienadzia Cychuna wyrazem wszechstronności ...

TSykhun, G. A. (1981). Tipologicheskie problemy balkanskogo iazykovogo areala. Nauka i tekhnika. Tsykhun, H. A. (1983). Paŭdniovaslavianska-ŭskhodneslavianskiia moŭnyia suviazi (da prablemy slavianskaha ŭkladu ŭ balkanski moŭny saiuz). Navuka i tèkhnika.

Tsykhun, H. A. (1988). Aréal'naia typalohiia slavianskikh moŭ: Pryntsypy i napramki dasledavannia: Daklad na X Mizhnar. z'ezdze slavistaŭ. Navuka i tèkhnika.

Tsykhun, H. A. (1998a). Arèal'naia struktura praslavianshchyzny. In J. Rusek \& W. Boryś (Eds.), Prasłowiańszczyzna i jej rozpad (pp. 73-77). Wydawnictwo "Energeia".

Tsykhun, H. A. (1998b). Slavianskiia movy ŭ sviatle ékalinhvistyki: Daklad na XII Mizhnar. z'ezdze slavistaŭ. Belaruski kamitèt slavistaŭ.

Tsykhun, H. A. (Ed.). (2004-2017). Ėtymalahichny sloŭnik belaruskă̌ movy (Vols. 9-14). Belaruskaia navuka.

Tsykhun, H. A. (2012). Vybranyia pratsy: Belarusistyka, slavistyka, aréal'naia linhvistyka. Belaruskaia navuka.

Tsykhun, H. A. (2013). Aspekty slavianskaĭ aréal'nă linhvistyki: Dakl. na XV Mizhnar. z'ezdze slavistaŭ. Prava i èkanomika.

Tsykhun, H. A. (2018). Prastora movy: Moŭnyia suviazi: Historyia sloŭ: Vybranyia pratsy (I. Volkava, Ed.). Belaruskaia navuka.

Wysoczański, W. (1999). Ekologia języka jako dyscyplina heterogenicznego opisu języka. Biuletyn Polskiego Towarzystwa Językoznawczego, 55, 63-76.

Zaprudski, S. (2011). Henadz' Apanasavich Tsykhun (da 75-hoddzia z dnia naradzhènnia). Belaruskaia linhvistyka, 2011(67), 174-178.

\section{A Volume of Henadz' Tsykhun's Selected Studies as a Testimony to His Wide- Ranging Interests in Slavic Linguistics}

\section{Summary}

This article is a review of Henadz' Tsykhun's volume of selected studies entitled Prastora movy: Moŭnyia suviazi: Historyia sloŭ: vybranyia pratsy [Language Space, Language Connections, History of Words: Selected Studies]. The reviewed work describes issues of language contact, sociolinguistics, etymology and terminology. The volume concerns widely understood Slavic studies in both diachronic and synchronic aspects, with a special emphasis on the Belarusian language. 


\title{
Wybór publikacji Hienadzia Cychuna wyrazem wszechstronności zainteresowań slawistycznych autora
}

\author{
Streszczenie
}

Niniejsza publikacja stanowi recenzję monografii Hienadzia Cychuna pt. Прастора мовы. Моўныя сувязі. Гісторыя слоў: выбраныя працы [Przestrzeń języka. Związki językowe. Historia słów. Wybrane opracowania]. Recenzowana praca opisuje zagadnienia kontaktów językowych, socjolingwistyki, etymologii oraz terminologii. Dotyczy szeroko rozumianej slawistyki zarówno w aspekcie diachronicznym, jak i synchronicznym, ze szczególnym uwzględnieniem języka białoruskiego.

Keywords: Slavic studies; Belarusian studies; linguistics; language contact; language ecology

Słowa kluczowe: studia słowiańskie, białoruskie studia, językoznawstwo, kontakty językowe, ekologia językowa

\footnotetext{
Jadwiga Kozłowska-Doda, Maria Curie Skłodowska University, Lublin, Poland ORCID: http://orcid.org/0000-0001-7567-178X

Correspondence: y.kazlouskaya-doda@poczta.umcs.lublin.pl

The preparation of this article was financed within the statutory activities of the Institute of Philology, Maria Curie Skłodowska University.

Competing interests: The author has declared that she has no competing interests.
} 